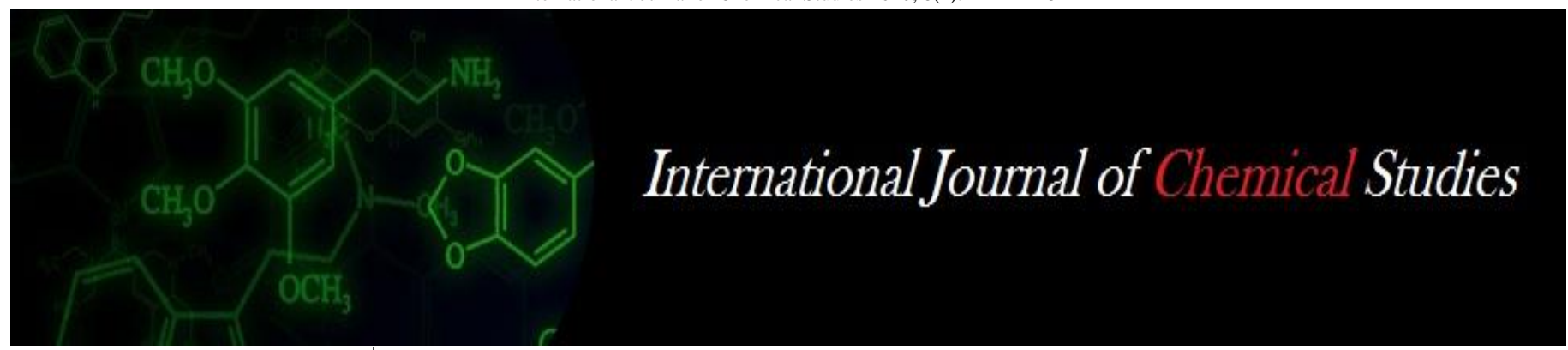

P-ISSN: 2349-8528

E-ISSN: 2321-4902

IJCS 2020; 8(1): 1411-1415

(C) 2020 IJCS

Received: 17-11-2019

Accepted: 20-12-2019

Mamta

Plant Biotechnology Centre,

Swami Keshwanand Rajasthan

Agricultural University, Bikaner,

Rajasthan, India

Y Sudarsan

Plant Biotechnology Centre,

Swami Keshwanand Rajasthan

Agricultural University, Bikaner,

Rajasthan, India

VP Agarwal

Plant Biotechnology Centre,

Swami Keshwanand Rajasthan

Agricultural University, Bikaner,

Rajasthan, India

Ishani Dogra

Plant Biotechnology Centre,

Swami Keshwanand Rajasthan

Agricultural University, Bikaner,

Rajasthan, India

\section{Aarif Khan}

Post Graduate Institute of

Veterinary Education and

Research, B-2 by pass, Shipra

Path, Mansarovar, Jaipur,

Rajasthan, India

Mansi Sharma

Plant Biotechnology Centre,

Swami Keshwanand Rajasthan

Agricultural University, Bikaner,

Rajasthan, India

Corresponding Author:

Mamta

Plant Biotechnology Centre,

Swami Keshwanand Rajasthan

Agricultural University, Bikaner,

Rajasthan, India

\section{Effect of terminal drought on morphological and physiological attributes of pearl millet (Pennisetum glaucum L.)}

\author{
Mamta, Y Sudarsan, VP Agarwal, Ishani Dogra, Aarif Khan and Mansi \\ Sharma
}

\section{DOI: $\underline{\text { https://doi.org/10.22271/chemi.2020.v8.i1t.8456 }}$}

\begin{abstract}
The present investigation was undertaken to study terminal drought tolerance on morphological and physiological characters in seven hybrids of pearl millet viz. GHB-558, GHB-732, HHB-67 improved, HHB-226, MPMH-17, RHB-173 and RHB-177. No irrigation was applied throughout the growth and developmental stages of the crop. The panicle length, panicle weight, grain yield per panicle, test weight, economical yield per plant, biological yield per plant and harvest index were recorded maximum in hybrid RHB-177 as compared to other hybribs. There was a significant variation among the hybrids for all the parameters recorded. Relative water content, membrane stability index and carotenoid content were also the highest in hybrid RHB-177 while chlorophyll content was the highest in RHB-173. On the basis morphological and physiological observations, it is deduced that RHB-177 has higher seed production potential than other hybrids considered to be the best suited. In comparative analysis, Hybrid RHB-177 was also found to be extremely tolerant; RHB-173 and GHB-558 tolerant; GHB-732, HHB-67 improved and HHB-226 moderately tolerant and MPMH-17 susceptible to drought stress.
\end{abstract}

Keywords: drought, physiology, tolerance, pearl millet

\section{Introduction}

Pearl millet (Pennisetum glaucum (L.) R. Br.) is one of the most important millet crops cultivated all over the world for grain and fodder. It ranks sixth in the world, after rice, wheat, maize, barley and sorghum in terms of area planted. It is widely grown in arid and semi-arid regions of Africa and Asia. India is the largest producer of this crop with an occupied area of $6.98 \mathrm{~m}$ ha with production and productivity of $8.06 \mathrm{~m} \mathrm{t}$ and $1154 \mathrm{~kg} \mathrm{ha}^{-1}$ (Anonymous, 2016) ${ }^{[2]}$, respectively. In India, the principle pearl millet growing states are Rajasthan, Uttar Pradesh, Gujarat, Madhya Pradesh Haryana, Maharastra and Karnataka which account for 95.79 per cent of the total area and 95.19 per cent production. Rajasthan occupies the first position in area (57.92 percent) and production (43.78 per cent) in India. In Rajasthan, it is cultivated on $4.04 \mathrm{~m}$ ha area with production and productivity of $3.53 \mathrm{~m} \mathrm{t}$ and $872 \mathrm{~kg} \mathrm{ha}^{-1}$ (Anonymous, 2016) ${ }^{[2]}$, respectively. The grains of pearl millet are very nutritious and good source of carbohydrate, protein, fat and minerals, particularly of phosphorus and iron.

Pearl millet, being a $\mathrm{C}_{4}$ plant is endowed with a very high photosynthetic efficiency and ability for dry matter production. It is a crop of hot and dry climates, and can be grown in areas where rainfall (200-600 mm) is not sufficient for maize and sorghum. Because of its tolerance to high temperature and better ability to withstand drought and to grow even in low soil fertility conditions, pearl millet is best suited for arid and semi-arid regions of the country (Khairwal et $a l ., 2007)^{[11]}$. However, the productivity in arid zone is lower due to low and erratic rainfall which is the single most important constraint to its production. Keeping in view the present investigation was undertaken to Screen seven Pearl millet hybrids for morphological and physiological characters.

\section{Materials and Methods}

Selection of site of experiment

The field experiment was carried out under RKVY project on "Molecular indexing of drought 
tolerance in pearl millet" at Agriculture Research Station, Swami Keshwanand Rajasthan Agricultural University, Bikaner. For yield attributing traits, plant samples were taken at the time of harvest. For physiological observations leaf samples were collected at the time of anthesis stage and stored in deep freezer $\left(-40^{\circ} \mathrm{C}\right)$ for further analysis.

\section{Field study}

The seeds of seven pearl millet hybrids viz. GHB-558, GHB732, HHB 67 (Improved), HHB-226, MPMH-17, RHB 173 and RHB 177 were raised in kharif, 2017. The experiment was laid out in Randomized Block Design with three replications. The plot(s) size were kept equal i.e. $4 \times 3.6 \mathrm{sq} \mathrm{m}$. Recommended row to row and plant to plant distance was kept at the time of sowing i.e. $60 \mathrm{~cm}$ and $15 \mathrm{~cm}$, respectively. All the recommended package of practices was followed. No irrigation was applied throughout the growth and developmental stages of the crop.

\section{Field observations}

From each plot five plants were randomly selected of each replication for measure of their average panicle length $(\mathrm{cm})$ and panicle weight $(\mathrm{g})$. Test weight is calculated from randomly taken sample of thousand threshed seeds of each variety in each replication and weighed in gram. For grain yield and biological yield randomly tagged ten plants they were threshed, weighed and averaged to obtain grain yield and plant parts above the ground were dried in sunlight for measure of average biological yield. From grain yield and biological yield harvest index was calculated.

\section{Laboratory analysis}

To calculate Physiological parameters such as Relative Water Content (RWC), Membrane Stability Index (MSI), Chlorophyll and Carotenoid content the method(s) as reported by Premchand et al., (1990) and Hiscox and Israelstom, $(1979)^{[10]}$ respectively.

\section{Statistical analysis}

The statistical analysis of the data was done using randomized block design, and critical differences were computed at the $5 \%$ probability level.

\section{Results}

\section{Morphological Parameters}

Data pertaining to panicle length, panicle weight, grain yield/panicle, panicle harvest index, grain yield, stover yield, harvest index and test weight are presented in Table-1.

\section{Panicle length $(\mathrm{cm})$}

The appraisal of data (Table-1) showed that the panicle length ranged from $19.19 \mathrm{~cm}$ to $22.13 \mathrm{~cm}$ and the hybrid as. Out of the seven pearl millet hybrids RHB-177 recorded the highest panicle length $22.13 \mathrm{~cm}$ followed by MPMH-17 $(22.09 \mathrm{~cm})$, GHB-558 (21.27 cm), GHB-732 (21.17 cm), HHB-226 (21.07 $\mathrm{cm})$, HHB-67 improved $(20.70 \mathrm{~cm})$ and RHB-173 $(19.99 \mathrm{~cm})$.

\section{Panicle weight (g)}

The scrutiny of data (Table-1) showed that the mean value for panicle weight ranged from $17.30 \mathrm{~g}$ to $33.90 \mathrm{~g}$. Out of the seven pearl millet hybrids RHB-177 recorded the highest panicle weight $33.90 \mathrm{~g}$ followed by GHB-558 (31.80 g), HHB-226 (28.00 g), MPMH-17 (20.80 g), GHB-732 (17.80 $\mathrm{g})$, RHB-173 (17.30 g) and HHB-67 improved (16.00 g).

\section{Grain yield/Panicle (g)}

A perusal of data (Table-1) reveals that the grain yield/panicle ranged from $14.00 \mathrm{~g}$ to $29.33 \mathrm{~g}$. Out of the seven pearl millet hybrids studied, the highest $29.33 \mathrm{~g}$ grain yield/panicle was observed in RHB-177, followed by GHB-558 (29.00 g), HHB-226 (24.66 g), MPMH-17 (20.12 g), HHB-67 (17.00 g), GHB-732 (15.07 g) and RHB-173 (14.00 g).

\section{Grain yield (g/plant)}

It is apparent from data (Table-1) that the mean value for economic yield ranged from $4.07 \mathrm{~g}$ to $11.20 \mathrm{~g}$ per plant. On the basis of mean performance, the hybrid RHB-177 recorded the highest $11.20 \mathrm{~g}$ seed yield per plant followed by GHB-558 (9.07 g), GHB-732 (8.00 g), RHB-173 (7.72 g), HHB-67 improved (7.39 g), HHB-226 (6.58 g) and MPMH-17 (4.07 g). Among the seven hybrids evaluated, hybrid RHB-177 recorded significantly higher seed yield per plant over other hybrids.

\section{Stover yield (g/plant)}

The stover yield of seven hybrids studied ranged from $20.98 \mathrm{~g}$ to $30.17 \mathrm{~g}$. The maximum $30.17 \mathrm{~g}$ stover yield per plant was exhibited by the hybrid RHB-177 followed by GHB-732 (29.17 g), GHB-558 (26.53 g), HHB-226 (24.76 g), HHB-67 improved $(24.10 \mathrm{~g})$, MPMH-17 (23.49 g) and RHB-173 (20.98 g) (Table-1).

\section{Harvest index}

Data (Table-1) revealed that the harvest index ranged from 14.77 to 27.08 per cent. The maximum harvest index was depicted by the hybrid RHB-177 (27.08 per cent) followed by RHB-173 (26.89 per cent), GHB-558 (25.47 per cent), HHB67 improved (23.46 per cent), GHB-732 (21.17 per cent), HHB-226 (21. per cent) and MPMH-17 (14.77 per cent).

\section{Test (1000- seed) weight (g)}

Data (Table-1) showed that the 1000- seed weight ranged 4.20 to $6.93 \mathrm{~g}$. Out of the seven pearl millet hybrids studied. RHB177 observed highest $6.93 \mathrm{~g}$ test weight followed by HHB- 67 improved (6.04 g), GHB- 732 (5.31 g), GHB- 558 (5.21 g), RHB- 173 (5.18 g), MPMH-17 (4.53 g) and HHB- 226 (4.20 g).

\section{Physiological Parameters}

Data pertaining to Relative Water Content, Membrane Stability Index, Chlorophyll Content and Carotenoid Content are presented in table- 2 .

\section{Relative water content (RWC)}

Data depicted (Table-2) indicated that mean value of RWC varied from 65.56 per cent to 77.66 per cent. The highest relative water content (RWC) was recorded in hybrid RHB177 (77.66 per cent) followed by HHB-226 (76.26 per cent), RHB-173 (73.99 per cent), GHB-558 (72.19 per cent), GHB732 (70.85 per cent), HHB-67 improved (66.09 per cent) and MPMH-17 (65.56 per cent.

\section{Membrane stability index (MSI)}

Data on membrane stability index (Table-2) showed that there was a significant variation in membrane stability index of seven hybrids of pearl millet. Membrane stability index of seven hybrids of pearl millet ranged from 14.46 per cent to 25.05 per cent. Maximum MSI 25.05 per cent was recorded in RHB-177 followed by GHB-732 (20.94 per cent), HHB-226 (19.31 per cent), HHB- 67 improved (18.96 per cent), 
MPMH-17 (18.38 per cent), RHB-173 (17.75 per cent) and GHB-558 (14.46 per cent).

\section{Chlorophyll content (mg g $\mathbf{~ g}^{-1}$ fr. Wt.)}

Data depicted (Table-2) reveals that there was significant variation in chlorophyll content among the hybrids. Out of the seven pearl millet hybrids studied, RHB-173 recorded the highest chlorophyll content $2.519 \mathrm{mg} \mathrm{g}^{-1} \mathrm{fw}$ followed by HHB-67 (2.507 mg g $\left.{ }^{-1} \mathrm{fw}\right)$, GHB-558 (2.503 $\left.\mathrm{mg} \mathrm{g}^{-1} \mathrm{fw}\right)$, MPMH-17 (2.431 mg g $\left.{ }^{-1} \mathrm{fw}\right)$, HHB-226 (2.185 $\left.\mathrm{mg} \mathrm{g}^{-1} \mathrm{fw}\right)$, RHB-177 (2.101 mg g-1 fw) and GHB-732 (1.724 $\left.\mathrm{mg} \mathrm{g}^{-1} \mathrm{fw}\right)$.

\section{Carotenoid content $\left(\mathrm{mg} \mathrm{g}^{-1} \mathbf{f r}\right.$. Wt. $)$}

A persual of data (Table-2) revealed that there is significant variation in carotenoid content among the hybrids. The highest $0.593 \mathrm{mg} \mathrm{g}^{-1}$ fw carotenoid content was recorded in hybrid RHB-177 followed by RHB-173 (0.486 $\left.\mathrm{mg} \mathrm{g}^{-1} \mathrm{fw}\right)$, HHB-226 (0.476 mg g $\left.\mathrm{m}^{-1} \mathrm{fw}\right)$, GHB-558 (0.455 $\left.\mathrm{mg} \mathrm{g}^{-1} \mathrm{fw}\right)$, HHB-67 improved (0.454 mg g-1 fw), GHB-732 (0.449 $\mathrm{mg} \mathrm{g}^{-1}$ fw) and MPMH-17 (0.244).

\section{Discussion}

It has become imperative to elucidate the responses and adaptation of crops to water deficit and take actions to improve the drought resistance ability of crop plants to ensure higher crop yields against unfavorable environmental stresses. Results reported in this paper have shown significant differences in morpho-physiological attributes of seven hybrids of pearl millet.

The susceptibility of plants to drought stress varies in dependence of stress degree, different accompanying stress factors, plant species, and their developmental stages (Demirevska et al., 2009) ${ }^{[5]}$. Drought impacts growth, yield, membrane integrity, pigment content, osmotic adjustment water relations, and photosynthetic activity (Benjamin and Nielsen, 2006; Praba et al., 2009) ${ }^{[4,14]}$. Acclimation of plants to water deficit is the result of different events, which lead to adaptive changes in plant growth and physio-biochemical processes, such as changes in plant structure, growth rate, tissue osmotic potential and antioxidant defenses (Duan et al., 2007) ${ }^{[6]}$.

Among the seven pearl millet hybrids studied, panicle length and weight are the important traits of yield. Examination of data showed that RHB-177 recorded the highest panicle length $22.13 \mathrm{~cm}$ followed by MPMH-17 $(22.09 \mathrm{~cm})$, GHB$558(21.27 \mathrm{~cm})$, GHB-732 $(21.17 \mathrm{~cm})$, HHB-226 $(21.07 \mathrm{~cm})$, HHB-67 improved $(20.70 \mathrm{~cm})$ and RHB-173 $(19.99 \mathrm{~cm})$ whereas, panicle weight of RHB-177 was observed to be the highest $33.90 \mathrm{~g}$ followed by GHB-558 (31.80 g), HHB-226 (28.00 g), MPMH-17 (20.80 g), GHB-732 (17.80 g), RHB173 (17.30 g) and HHB-67 improved (16.00 g). So, panicle length and panicle weight were the highest in hybrid RHB177 over other hybrids. Kumar and Rao (1987) had also reported variation in panicle length of Oasis and Zongo forms of pearl millet.

Grain yield per panicle was the highest $29.33 \mathrm{~g}$ in RHB-177 followed by GHB-558 (29.00 g), HHB-226 (24.66 g), MPMH-17 (20.12 g), HHB-67 improved (17.00 g), GHB-732 $(15.07 \mathrm{~g})$ and RHB-173 (14.00 g). Test (1000-seed) weight was also the highest $6.93 \mathrm{~g}$ in hybrid RHB-177 followed by HHB-67 (6.04 g), GHB-732 (5.31 g), GHB-558 (5.21 g), RHB-173 (5.18 g) MPMH-17 (4.53 g) and HHB-226 (4.20 $\mathrm{cm})$.

Yield is a complex character governed by a large number of genes and environmental factors and their association and interaction. The deficiency of water leads to severe decline in yield traits of crop plants probably by disrupting leaf gas exchange properties which not only limit the size of the source and sink tissues but also phloem loading, assimilate translocation and dry matter partioning (Farooq et al., 2009) [7]. In general, the hybrid RHB-177 recorded the highest seed yield $(11.20 \mathrm{~g})$ and stover yield $(30.17 \mathrm{~g})$ per plant. There were significant variations among the pearl millet hybrids in respect to yield. Harvest index was also the highest recorded in RHB-177 (27.08 per cent) followed by RHB-173 (26.89 per cent), GHB-558 (25.47 per cent), HHB-67 improved (23.46 per cent), GHB-732 (21.17 per cent), HHB-226 (21.01 per cent) and MPMH-17 (14.77 per cent). The hybrid RHB177 showed highest panicle length \& weight, grain yield per panicle, test weight, stover yield, economical yield and harvest index among the seven hybrids of pearl millet. Higher yield potential of RHB-177 under rainfed conditions exhibited the existence of drought tolerance mechanism through better management of gas exchange parameters, stomatal regulation, membrane stability, photosynthetic pigments and osmotically active metabolites at critical growth stages. Zaman et al., (2004) ${ }^{[18]}$ reported a range of 12.3 to $56.5 \mathrm{t} \mathrm{ha}^{-1}$ while evaluating nine varieties of pearl millet. Naeem et al., (2003) [13] also observed significant differences among the pearl millet genotypes for green fodder yield. High fodder yield is closely associated with high values for plant height, number of leaves, number of tillers per plant and leaf area.

Pearl millet hybrids differed significantly in relative water content (RWC), membrane stability index (MSI), chlorophyll and carotenoid content. RWC was the highest in hybrid RHB177 (77.66 per cent) followed by HHB-226 (76.26 per cent), RHB-173 (73.99 per cent), GHB-558 (72.19 per cent), GHB732 (70.85 per cent), HHB-67 improved (66.09 per cent) and MPMH-17 (66.56 per cent). Maximum MSI was recorded in RHB-177 (25.05 per cent) followed by GHB-732 (20.94 per cent), HHB-226 (19.31 per cent), HHB-67 improved (18.96 per cent), MPMH-17 (18.38 per cent), RHB-173 (17.75 per cent) and GHB-558 (14.46 per cent). The highest chlorophyll content was reported in RHB-173 (2.519 mg g-1) followed by HHB-67 improved (2.507 $\left.\mathrm{mg} \mathrm{g}^{-1}\right)$, GHB-558 (2.503 $\left.\mathrm{mg} \mathrm{g}^{-1}\right)$, MPMH-17 (2.431 $\left.\mathrm{mg} \mathrm{g}^{-1}\right)$, HHB-226 (2.185 mg g-1) RHB-177 $\left(2.101 \mathrm{mg} \mathrm{g}^{-1}\right)$ and GHB-732 (1.724 mg g $\left.\mathrm{mg}^{-1}\right)$. The highest $0.593 \mathrm{mg} \mathrm{g}^{-1}$ carotenoid content was reported in RHB-177 followed by RHB-173 (0.486 $\left.\mathrm{mg} \mathrm{g}^{-1}\right)$, HHB-226 (0.476 $\mathrm{mg} \mathrm{g}^{-}$ $\left.{ }^{1}\right)$, GHB-558 (0.455 $\left.\mathrm{mg} \mathrm{g}^{-1}\right)$, HHB-67 improved $\left(0.454 \mathrm{mg} \mathrm{g}^{-}\right.$ $\left.{ }^{1}\right)$, GHB-732 (0.449 $\left.\mathrm{mg} \mathrm{g}^{-1}\right)$ and MPMH-17 (0.244 $\left.\mathrm{mg} \mathrm{g}^{-1}\right)$.

In general, relative water content (RWC), cell membrane stability index (MSI) and carotenoid content were highest in hybrid RHB-177 and chlorophyll content was the highest in hybrid RHB-173. RWC and carotenoid content were minimum in hybrid MPMH-17 whereas MSI and chlorophyll content were minimum in hybrid GHB-558 and GHB-732, respectively. Guoth et al. (2009) ${ }^{[8]}$ observed that water status decreased at a higher rate in sensitive than in the tolerant cultivars of wheat. Membrane stability index decreased significantly under water stress in all the hybrids of pearl millet. GHB-558 always maintained higher stability (less injury) than other hybrids under water stress conditions. It is well known that the water stress causes accumulation of reactive oxygen species (ROS) which result in membrane damage. Higher membrane stability in GHB-558 reflects the existence of stress tolerance mechanism. Lower membrane stability in susceptible genotypes of wheat has been reported by Gupta et al. $2000^{[9]}$ and Aarif et al. $2019^{[1]}$. 
Gupta et al. (2000) ${ }^{[9]}$ reported that water stress invariably reduced the chlorophyll content but its reduction was lower in tolerant wheat genotypes. Carotenes are responsible for scavenging of singlet oxygen and hence their comparative level in a genotype can determine its relative tolerance. Vijayalakshmi et al. (2012) ${ }^{[17]}$ revealed significant positive association of yield at $0.01 \%$ level with relative water content, leaf water potential, stomatal conductance, photosynthesis, proline, total soluble sugars, free amino acids, membrane stability index, leaf area index and total biomass, while a significant negative association with solute potential and malondialdehyde content, under water-deficit stress clearly indicating that such relationships can be positively attributed to drought tolerance. A similar result has also been reported by Arnon (1984) ${ }^{[3]}$, Shah and Prathapasenan (1991) ${ }^{[16]}$ and Sairam et al. $(1991)^{[15]}$.

Table 1: Effect of terminal drought on yield and yield attributes in seven hybrids of pearl millet.

\begin{tabular}{|c|c|c|c|c|c|c|c|}
\hline Hybrids & $\begin{array}{c}\text { Panicle length } \\
\text { (cm) }\end{array}$ & $\begin{array}{c}\text { Panicle } \\
\text { weight (g) }\end{array}$ & $\begin{array}{c}\text { Grain yield/panicle } \\
\text { (g) }\end{array}$ & $\begin{array}{c}\text { Grain yield/plant } \\
\text { (g) }\end{array}$ & \begin{tabular}{|c|}
$\begin{array}{c}\text { Stover yield/plant } \\
(\mathrm{g})\end{array}$ \\
\end{tabular} & $\begin{array}{c}\text { Harvest } \\
\text { index }(\%)\end{array}$ & \begin{tabular}{|c|}
$\begin{array}{c}\text { Test weight } \\
\text { (g) }\end{array}$ \\
\end{tabular} \\
\hline GHB-558 & 21.27 & 31.80 & 29.00 & 9.07 & 26.53 & 25.47 & 5.21 \\
\hline GHB-732 & 21.17 & 17.80 & 15.07 & 8.00 & 29.77 & 21.17 & 5.31 \\
\hline HHB-67 improved & 20.70 & 16.00 & 17.00 & 7.39 & 24.10 & 23.46 & 6.04 \\
\hline HHB-226 & 21.07 & 28.00 & 24.66 & 6.58 & 24.76 & 21.01 & 4.20 \\
\hline MPMH-17 & 22.09 & 20.80 & 20.12 & 4.07 & 23.49 & 14.77 & 4.53 \\
\hline RHB-173 & 19.99 & 17.30 & 14.00 & 7.22 & 20.98 & 26.89 & 5.18 \\
\hline RHB-177 & 22.13 & 33.90 & 29.33 & 11.20 & 30.17 & 27.08 & 6.93 \\
\hline $\operatorname{S.Em}( \pm)$ & 0.55 & 0.70 & 1.38 & 0.15 & 0.26 & 0.45 & 0.19 \\
\hline $\mathrm{CD}(5 \%)$ & 1.69 & 2.16 & 4.25 & 0.46 & 0.80 & 1.39 & 0.59 \\
\hline $\mathrm{CV}$ & 4.47 & 5.13 & 11.20 & 3.28 & 1.78 & 3.41 & 6.26 \\
\hline
\end{tabular}

Table 2: Effects of terminal drought on mean of relative water content, membrane stability index, chlorophyll and carotenoid content in seven hybrids of pearl millet.

\begin{tabular}{|c|c|c|c|c|}
\hline Hybrids & Relative water content (\%) & Membrane stability index (\%) & Chlorophyll content (mg g $\mathbf{~}^{-1}$ & Carotenoid content (mg g $^{-\mathbf{1}}$ ) \\
\hline GHB-558 & 72.19 & 14.46 & 2.503 & 0.455 \\
\hline GHB-732 & 70.85 & 20.94 & 1.724 & 0.449 \\
\hline HHB-67 improved & 66.09 & 18.96 & 2.507 & 0.454 \\
\hline HHB-226 & 76.26 & 19.31 & 2.185 & 0.476 \\
\hline MPMH-17 & 65.56 & 18.38 & 2.431 & 0.244 \\
\hline RHB-173 & 73.99 & 17.75 & 2.519 & 0.486 \\
\hline RHB-177 & 77.66 & 25.05 & 2.101 & 0.593 \\
\hline S.Em( \pm ( & 2.84 & 0.73 & 0.210 & 0.030 \\
\hline CD $(5 \%)$ & 8.75 & 2.25 & 0.650 & 0.090 \\
\hline CV & 6.86 & 6,56 & 15.15 & 9.92 \\
\hline
\end{tabular}

\section{Conclusion}

It can be concluded that on the basis of yield characters hybrid RHB-177 has higher yield potential among all the hybrids. RHB-177 was found extremely suitable; RHB-173 and GHB-558 were found suitable; GHB-732, HHB-67 improved and HHB-226 were found moderately suitable and MPMH-17 was found low yielding under rainfed conditions.

\section{Reference}

1. Aarif K, Gupta NK, Rizwan M, Govind S. Effect of high temperature stress on physiological attributes and antioxidative defense mechanism in wheat (Triticum aestivum L.). International Journal of chemical studies. 2019; 7(5):2183-2187.

2. Anonymous. Agricultural Statistics at a Glance, Ministry of Agriculture and Farmers welfare, Department of Agriculture, Co-operation and Farmers welfare, Directorate of Economics and Statistics Govt. of India, New Delhi, 2016.

3. Arnon I. Effect of Gibberellin and Chlorocholine chloride on photosynthetic apparatus and growth of barley plant. Rostrastenill regulyastisia, Moscow, USSR. (Russia). 1984; 19:18-25.

4. Benjamin JG, Nielsen DC. Water deficit effects on root distribution of soybean, field pea and chickpea. Field Crops Research. 2006; 97:248-253.

5. Demirevska K, Zasheva D, Dimitrov R, Simova-Stoilova L, Stamenova M, Feller U. Drought stress effects on rubisco in wheat: Changes in the rubisco large subunit. Acta physiologiae plantarum. 2009; 31:1129-1138.

6. Duan B, Yang Y, Lu Y, Korpelainen H, Berninger F, Li C. Interactions between drought stress, ABA and genotypes in Picea asperata. Journal of Experimental Botany. 2007; 58:3025-3036.

7. Farooq M, Wahid A, Kobayashi N, Fujita D, Basra SMA. Plant drought stress: Effects, mechanisms and management. Agronomy for Sustainable Development. 2009; 29:185-212.

8. Guoth A, Tari I, Galle A, Csiszar J, Pecsvaradi A, Cseuz L et al. Comparison of the drought stress responses of tolerant and sensitive cultivars during grain filling: changes in flag leaf photosynthetic activity, ABA levels and grain yield. Journal of Plant Growth Regulation. 2009; 28:167-176.

9. Gupta NK, Gupta S, Kumar A. Exogenous cytokinin application increases cell membrane and chlorophyll stability index in wheat. Cereal Research Communication. 2000; 28:297-281.

10. Hiscox JD, Israelstam GF. A method for extraction of chloroplast from leaf tissue without maceration. Canadian Journal of Botany. 1979; 57:133-1334.

11. Khairwal IS, Yadav SK, Rai KN, Upadhyaya HD, Kachhawa D, Nirwan B et al. Evaluation and identification of promising pearl millet germplasm for grain and fodder traits. Journal of SAT Agricultural Research. 2007; 5:1-6. 
12. Kumar A, Rao A. Diversity and utilization of pearl millet germplasm. In: Proc. Int'l. Pearl Millet Workshop, ICRISAT, Patancheru, India, 1987, 69-82.

13. Naeem M, Chohan MSM, Khan AH, Din SS. Study of green fodder yield potential and its components of different pearl millet varieties under irrigated conditions of Faisalabad. Asian Journal of Plant Science. 2003; 2(1):74-76.

14. Praba ML, Cairns JE, Babu RC, Lafitte HR. Identification of physiological traits underlying cultivar differences in drought tolerance in rice and wheat. Journal of Agronomy Crop Science. 2009; 195:30-46.

15. Sairam RK, Deshmukh PS, Shukla DS. Influence of CCC on photosynthesis and nitrate assimilation in wheat genotypes under water stress. Indian Journal of Plant Physiology. 1991; 34:222-227.

16. Shah T, Prathapasenan G. Effect of cycocel on the growth and yield of Mungbean [Vigna radiata (L.) Wilczek var. Guj-2] Journal of Agronomy and Crop Science. 1991; 166(1):40-47.

17. Vijayalakshmi T, Varalaxmi Y, Jainender S, Yadav SK, Vanaja M, Jyothilakshmi $\mathrm{N}$ et al. Physiological and biochemical basis of water-deficit stress tolerance in pearl millet hybrid and parents. American Journal of Plant Science. 2012; 3:1730-1740.

18. Zaman Q, Malik NH, Hayat K. Performance of millet varieties for green fodder production under D.I. Kshan condition. Sarhad Journal of Agriculture. 2004; 20(1):4749. 